Kohl: a Journal for Body and Gender Research

Vol. 3, No. 1 (Summer 2017)

\title{
(Dis)-Intersecting Intersectionality in the Time of Queer Syrian Refugee-ness in Lebanon
}

Sabiha Allouche

\begin{abstract}
:
This paper heeds Jasbir Puar's call to supplement an intersectional analysis with an exercise of assemblage when examining identity politics. It argues that asylum organizations' unwillingness to account for the interplay between the receiving state (in this case Lebanon) and the lived reality of (Syrian) LGBT refugees results in a "one size fits all" narrative that forces the latter into a more visible and potentially death-instigating corporeality.

The interplay between refugees and the receiving state is summed up in the elitist discourse of a "Syrian neo-invasion" that results in the revival of an "authentic Lebanese masculinity." Whereas the Syrian refugee is vilified as "rapist" in a heterosexual context, they are emasculated as "necessarily bottom" in a same-sex one. This discourse is hegemonized through its emergence at the intersection of sect, political loyalty, and class.

At the empirical level, this paper draws on narratives recollected during fieldwork in order to show the limits of an analysis that takes identity politics as given, as seen in asylum organization's westernimbued "fixed" interpretations of what LGBT identities should "look like" and "act like."
\end{abstract}

\section{Acknowledgments:}

I would like to thank my colleagues at SOAS University of London, Dr. Caroline Osella, Dr. Rahul Rao, and Lewis Turner, for their valuable feedback when my paper was in its early stages. I would also like to thank the blind referees for their useful suggestions for how to improve my paper, and Kohl's team of translators for their work on the Arabic version. 
In July 2012, a popular TV show on the Lebanese TV network MTV, anta hurr (You are Free) - a tabloid show by the best standards - was attacked unanimously along with its host, Joe Maalouf, for publically humiliating, notably by naming and shaming, a group of men caught watching pornographic material and having sex with other men in a dysfunctional cinema theatre named Cinema Plaza. Not only were these men's faces showed on TV along with their names, the cameraman "actively lured" some of the men to engage in sexual relationships in the bathroom (Mandour 2013:7). Thirty-six men in total were arrested, and several of them were "anally" tested (ibid). These tests supposedly prove one's involvement in practices of sodomy. They are not sanctioned by the law and continue to be practiced by Lebanon's Interior Security Forces (ISF) in instances where same-sex activity is suspected.

Hours after the episode was aired, social media became enflamed with comments of enraged viewers. The next day, another popular TV network, LBCl, harshly criticized the episode and accused the Lebanese state of "raping" the detained men (ibid). Even the then Minister of Interior, Marwan Charbel, admitted his disappointment and showed what appeared to be genuine concern vis-à-vis the episode in question at the time. Shortly, when addressing same-sex relations in Lebanon, a number of newspapers and TV networks alike switched from a rather reproachful narrative to a more empathetic one. Like many, I started wondering whether a substantial change was in the making.

Less than a year after the Cinema Plaza events, another moral panic occurred, this time in the Dekwaneh district. GHOST, a nightclub known for hosting "gay" parties, was raided by members of the ISF under the watchful eye of the mayor of Dekwaneh, Antoine Shakhtoura. ${ }^{1} \mathrm{~A}$ number of patrons filmed the raid and uploaded the footage to social media. Three men suspected of homosexuality and one transsexual woman were arrested. According to one of the detained men, a Syrian national, the arrest was both violent and humiliating, and included verbal harassment, physical beating, stripping, and the simulation of sexual acts (Raynbow Lebanon, 2013). Moreover, and according to the same individual, "they [the ISF] were insulting them extensively... They asked whether they would behave similarly had they been in Syria... and remarked 'look at what Syria brings us'..." (ibid).

However, when the very same Joe Maalouf covered the events of Dekwaneh for his show, criticizing the actions of both Shakhtoura and the ISF in what could be seen as an act of redemption, he was swiftly fired from MTV. MTV's decision to fire Maalouf had little to do with his "one sided pretentious monologue," one of the many reasons cited by MTV's director Jihad El-Murr as we learn from his Twitter account (Mandour, 2013). In the case of Dekwaneh, it was the mayor of Dekwaneh who was targeted by activists and by LBCI in its news bulletin. By Lebanon's standards, Antoine Shakhtoura is a za'im (boss), one of Lebanon's regional and locally strong zu'ama (bosses), and one simply "does not mess with the za'im." Between parentheses, I am using the expression za'im as an all-encompassing expression that can account for Lebanon's deeply rooted institution of clientalism, where political representation or more precisely political loyalty is enmeshed with sect and class. Conversely, a more

\footnotetext{
${ }^{1}$ Sahar Mandour (2013) was first to contrast the events of Cinema Plaza with those of GHOST nightclub in her excellent analysis of the interplay between each of Lebanon's media, politico-sectarian system, and civil society. I draw on her selected cases in order to set the context of this paper, to name the interaction between the Lebanese State and the discourse of sexuality in Lebanon.
} 
adequate description for Shakhtoura is that of a loyalist (in his case to Michel El-Murr, the owner of MTV).

The events of GHOST and Cinema Plaza are one example that highlights the violent episteme of sexuality, or sexuality as a source of control in contemporary Lebanon. Both events show how the celebrated image of Lebanon-as-exception is ultimately dictated by what could be described as a tag of war interplay between its "social order" on the one hand, and its political class on the other. In other words, the local za'im capitalizes on homo-moral panics in order to promote their agendas.

In the case of Dekwaneh, the actions of its mayor Antoine Shakhtoura could be simply described as "homophobic" for the untrained eye. However, such views are limited and do not take into account the deeply rooted links between sexuality, masculinity, and power in Lebanon. As was the case with the Queen Boat incident in Cairo in May 2001, the Dekwaneh events, far from resulting from Shakhtoura's homophobic beliefs, provided him with an opportunity to "perform a discourse of national security through which national sovereignty was (re)produced and political order was maintained" (Pratt 2007: 129). The targeting of the nationality of the arrested individuals ("Look at what Syria brings us!") is one opportunity that allows Shakhtoura to maintain his deplorable treatment of Syrian refugees in the neighborhood of Dekwaneh, such as the imposition of curfews on Syrian refugees. Moreover, it stresses the "grotesque" aspect of those targeted. Ahmed (2000:53) argues, "the over-representation of strange bodies as grotesque already positions the bodies of those that are not yet subjects, as out of place precisely in their refusal to be contained by place."

The imminent use of violence by the ISF during the events of GHOST and following the arrest of the thirty-six men suspected of same-sex activity brings forth the work of Paul Amar (2011). A lazy analysis would locate the ISF's actions in the discourse of a Middle Eastern masculinity "in crisis" where violence, religious extremism, and a predatory sexuality are taken "as given," instead of acknowledging the role of the state's "securitization logic," as Amar (2013) reminds us, which constructs certain men as objects of fear that ought to be controlled, and ultimately coerced into its apparatus. In other words, Amar is inviting us to distance ourselves from the limited lens of geopolitics that addresses sexuality without paying enough attention to the role of the state in constructing masculinities (and femininities).

Two main threads guide this paper. The first relates to the role of the Lebanese state in the construction of a nationalistic masculinity that results in the Othering of Syrian refugees; the second to the consequences of said construction on the lived reality of LGBT Syrian refugees. Having said that, this paper draws on data recollected during fieldwork ${ }^{2}$ and on the fields of gender and sexuality studies, refugee studies, and critical International Relations (IR) in order to argue that asylum organizations' unwillingness to account for the interplay between the receiving state (in this case Lebanon) and the lived reality of Syrian LGBT refugees results in a "one size fits all" narrative that forces the latters into a dangerous corporeality.

\footnotetext{
2 The data I relate in here were recollected alongside fieldwork that was originally conducted for the purpose of my doctoral thesis between January 2014 and September 2014. When I decided to write a paper about my findings, I conducted further interviews 2015 both in person (when I went to Lebanon to visit my family), and via Skype. In total, 6 LGBT Syrian refugees - 4 of whom were applying for asylum, 14 self-identified gay Lebanese men, and 5 gender activists working for various local and international NGOs were interviewed.
} 
I first relate important notes on the notion of refugee in order to critique mainstream and non-critical depictions of it. I then situate the context of this paper by theorizing the current backlash against Syrian refugees in Lebanon as a "Syrian neo-invasion." I argue that this backlash/discourse is hegemonized through the intersection of Lebanon's ruling elite with political loyalty and class; additionally, it draws its (imagined) legitimacy from the elite's appropriation of the national fervor that accompanied the Cedar Revolution in 2005. Through discourse analysis and interviews with LGBT Syrian refugees, I show the interplay between the discourse of "Syrian neo-invasion" with masculinity and the nation: the Syrian refugee is vilified as "rapist" in a heterosexual context, and emasculated as "necessarily bottom" in a homosexual one. At a second stage, I show the limits of an analysis that takes identity politics as given, as seen in western-imbued asylum organizations' "fixed" interpretations of what LGBT identities should "look like" and "act like." Ultimately, I am heeding Jasbir Puar's call to supplement intersectional analyses with an exercise of assemblage(s) when attempting to understand identity politics.

\section{Notes on Refugee-ness}

Whereas the literature on Syrian refugees in Lebanon and elsewhere is in its genesis, much work has been done on Palestinian refugees living in Lebanon. Still, it is important to point out that the majority of the Syrian refugees population in Lebanon is best understood along "(non)-encampment" lines, seeing how the Lebanese economy "requires" large numbers of "non-encamped" and "low-wage" Syrian workers (Turner, 2015). Consequently, we should broaden our understanding of the "camp" from a "space of humanitarianism" to a "tool" that permits states to spatially segregate certain refugees in accordance with their economic goals (ibid). We can recognize further processes of instrumentalization in the context the Palestinian population, as I will show hereafter.

By the time Syrian refugees started entering Lebanon in 2012, little progress had been made in regards to the Palestinian refugee population who has been present in Lebanon since 1948. Although Christian Palestinian refugees have found it traditionally easier to obtain Lebanese citizenship, particularly during Camille Chamoun's mandate in the 1950's (Knudsen 2009), today, Julie Peteet (2005: 174) rightly points out that a refusal to settle refugees can be seen across the sectarian board in Lebanon as evident in the slogan of "Lebanon for the Lebanese." In addition, Knudsen (2009: 68) argues that engaging with the resettlement question becomes a "futile" exercise when "opposed by powerful elites and patrons [mostly members of parliament] supported by public opinion," and even when attempts are made to revive it, the executive branch's capacity is limited considering the existing labour laws that are in place.

Roughly 451,000 Palestinians are registered with the UNRWA (United Nations Relief and Works Agency for Palestine Refugees in the Near East). Lebanon's fragile demographics, measured in quasiequal proportions of Christians and Muslims, is often cited as the reason behind the exclusion of Palestinian refugees from civil society and the Lebanese' state reluctance in naturalizing them (Knudsen 2009). This exclusion is telling of the temporal meaning we wrongly ascribe to the status of refugee. 
By ascribing a temporal meaning to the life of the refugee, we limit their lived reality to the narrative of "returning home," as if such a move is possible in the first place. Similarly, a temporal understanding denies the asymmetry between the legal meaning and the social meaning of the refugee as is evident in mainstream political analyses. Palestinians residing in Lebanon continue to be treated as "secondclass" citizens despite residing in Lebanon for decades. ${ }^{3}$ In fact, it is common to hear Lebanese people complain, "how easy Palestinians have it" since all they have to do is register with the UNRWA in order to receive monthly allowances. This discourse is often contrasted with the many crises that ply the lives of Lebanese citizens: from the hush infrastructure of the country (including roads, water, electricity, and telecommunication), to its opaque bureaucratic practices, and the inevitability of migrating, sooner or later, seeing the scarcity of "good jobs," especially when we compare it to Lebanon's high percentage of university-educated youth.

Such essentialist views about who counts as a refugee or what the category of refugee consists of are both limiting and hindering. Not only do they annihilate the subjectivity of refugees by reducing their lived reality to a mere legal term, they fail to account for the complexities of the dynamics between refugees and the larger society. For instance, Peteet (2005) alerts us to the fact that Palestinians living in Lebanon avoided referring to themselves as "refugees" for the largest part of their stay since they viewed themselves as a resistance movement, and it wasn't until their livelihood became institutionalized with the advent of the UNRWA with whom they were expected to register in return for a number of services that they started referring to themselves as "refugees." We learn from Peteet (2005: 210) that the legal meaning of the refugee status among Palestinians in Lebanon is not constant, and although it is "a category of persons with international recognition," its local meaning "shift in tandem with alterations in the power of the resistance movement" in Palestine. Peteet's findings resonate with those of Bernadette Ludwig (2013) who worked on the context of U.S. Resettlement Program. Ludwig (2013: 6) shows disproportionalities between the legal meaning of the refugee, and the "informal" or social one:

Forced migrants identify as refugees when this identification leads to international protection, resettlement in the US, and access to government benefits, but, on the other hand, reject the refugee label when it is not tied to resources and is a reminder of past suffering and a stigma.

Both Peteet and Ludwig show how the category of the refugee exceeds its legal core, and in what follows we will see how LGBT Syrian refugees are simultaneously constructed in the imaginary of both the receiving society and asylum officials, whose pre-conceived definitions about how an LGBT life ought to be enacted and lived endangers their livelihood. In what follows, I show how the Syrian refugee is absorbed by the slogan of "Lebanon is for the Lebanese," in addition to being constructed by Lebanon's elite along the narrative of a "neo-invasion," the origins of which can be traced back to the 2005 Cedar Revolution.

\footnotetext{
${ }^{3}$ Recent works that have engaged with the inequalities faced by the Palestinian population in Lebanon include Halabi (2004), Roberts (2011), and Czajka (2012).
} 


\section{Syrian Refugee-ness as "Neo-Invasion"}

When the Taïf Agreement ${ }^{4}$ was signed among Lebanon's multiple fractions in 1989, effectively ending Lebanon's civil war, Lebanon became de facto under Syria's hegemony. Did the Taif accords put an end to the internal wars of Lebanon's multiple politico-sectarian fractions? Or did they simply transform them from a politico-sectarian battleground to an unleashed neoliberal playground? Such interrogations are beyond the scope of this paper but are crucially important in order to fully grasp the socio-economic underpinnings of the anti-Syrian refugee discourse in Lebanon.

Following the assassination of Rafik Hariri on 14 February 2005, the Lebanese population (with the exception of the supporters of the party of Hezbollah, the majority of whom are Shi'a) took to the streets in what could be described as an extraordinary spectacle of an aesthetically-catalyzed union demanding the immediate withdrawal of Syrian troops form Lebanon. In gender terms, the 2005 Cedar Revolution meant that for the first time since the end of the civil war, a Lebanese masculinity, long lost under Syria's hegemony, or strictly channeled through it to be more exact, could finally be reclaimed and enacted. ${ }^{5}$ This reclaimed masculinity could be found at every level of Lebanon's hierarchy of masculinities: from the Lebanese za'im, or Lebanon's notorious politico-sectarian male leader, experiencing his first "100 percent Lebanese" speech ever, to the average Lebanese man who no longer had to whisper his anti-Syrian sentiments, those Lebanese men rarely felt as proud about their Lebanese-ness as on 14 March 2005. Conversely, an analysis that overlooks the intermingling between masculinity, Lebanese citizenship, and the history of the relationships between Lebanon and Syria is amiss, to say the least.

The influx of Syrian refugees must be seen against the backdrop of the 2005 Cedar Revolution, combined with the stagnant question of Palestinians' resettlement and the elite's instrumentalisation of foreign bodies in order to perform national sovereignty. In what follows, I argue that the revival of the discourse of "the authentic Lebanese man" occurs in the systematic labeling of Syrian refugees as "rapists" in a heterosexual context, and as "necessarily bottom" in a same-sex context.

\footnotetext{
${ }^{4}$ The Taiff Agreement is named after the city of Taiif in Saudi Arabia, where Lebanese parliamentarians agreed to meet in 1989. They signed the Document of National Understanding, which put and end to the Civil War, in addition to declaring the return of displaced persons as a necessary condition for permanent reconciliation and sustainable peace (Assaf and El-Fil, 2000). Nevertheless, the Taif Agreement allowed for the integration of warlords into Parliament, and its applied balanced sectarian system of appointments permitted a high degree of corruption, not to mention the country's overall confessional deadlock (Makdisi and El-Khalil, 2013).

${ }^{5}$ Whereas I focus on masculinity in my paper, it is important that I stress that the Cedar Revolution crystallized a hegemonic Lebanese femininity in the eyes of Arab (and possibly global) audiences as they gazed at the "elegant" and "classy" Lebanese woman whose construct continues to be reiterated in order to distinguish Lebanon from its immediate surrounding. Additionally, the Cedar Revolution reflected a collective "Lebanese national identity" on an unprecedented level in the history of modern Lebanon. At the same time, the Cedar Revolution clearly visual-ized a division between Lebanon's Shi'a demographic and further ones, the result of which can be seen in the now well-established opposing camps of 8 March and 14 March.
} 
Whereas the literature abounds with works maintaining women's burden as representative of the nation in the Middle East, and rightly so, I argue that this representation has been gradually becoming the responsibility of men in Lebanon since the arrival of Syrian refugees in 2010. In other words, a discourse encouraging the return of an "authentic Lebanese man" is increasingly discernable. This discourse, unsurprisingly, occurs in both non-heterosexual and heterosexual contexts.

Sexuality, understood as a source of control, is particularly noticeable in the construction of the discourse of the "villain" Syrian refugee man, as seen in the number of rape accusations against the latter, the majority of which being unfounded and unsubstantiated (Gagné and Qubaia, 2014). In such instances, sexuality is deployed in order to distinguish between an authentic camp (Lebanese) and a foreign one (Syrian). It is reminiscent of the "control/care paradigm" as configured by Suad Joseph (2005), where women as representative of the nation and bearers of the sons of the nation are cared for by men. When rape occurs, we can discern a miscarriage in the duties of the Lebanese man who failed to protect Lebanese women from the "rampant Syrian refugee." Not only do these accusations bear exclusive weight on the nationality of the perpetrator rather than on the act of rape itself, they imagine the Syrian refugee as a sexual predator and a threat, and relocate rape to a strictly foreign space - as if rape were alien to the Lebanese society.

Such episodes of moral panics prove the imaginary component of both sexuality and the nation. The Lebanese woman is "imagined" as an elevated member of the society beyond the reach of the destitute Syrian male refugee. The systematic villainization of the male Syrian refugee is one of many examples whereby certain bodies are deemed more worthy than others. By successfully accessing the body of a female Lebanese national, the Syrian refugee is presumed to have ignored his place, and to have bypassed the limits of Lebanon's hospitality. Most importantly though, by accentuating the foreignness of the perpetrator, we are acknowledging the defeat of the Lebanese male. When the Lebanese male is defeated, an "ethics of purity," defined by Cynthia Cockburn (1999) as a reminder of women's cultural authenticity that is deeply rooted in patriarchal assumptions of women's roles, prevails; and it results in a "siren call that few men can resist," according to Joane Nagel (1998:252).

In the context of Syrian refugees fleeing to Lebanon, this siren call has been taken by a number of its most prominent zaims, notably those who are considerably opposed to the pro-Assad party of Hizbollah, whose armed faction is openly fighting alongside the Syrian army. Without going into the details of the za'ims in question, it suffices to say that Lebanon's highly complex consociationalist political system, combined with its recent history of Pax Syriana, results in various degrees of Othering, with Sunni leaders being somewhat more conservative in their anti-Syrian sentiments than their Christian peers. Still, this does not necessarily absolve them from the crystallization of the discourse of the Syrian Other, once we consider the narratives of their loyal fractions.

The discourse of the Syrian Other is akin to a precipitated amnesia that neglects and negates the transnational endurances between those communities that reside alongside Lebanon and Syria's borders. These communities have long invested in transnational processes of kin alliances, i.e. marriage, entrepreneurial ventures, and further practices. In fact, a large number of Lebanon's poorest 
populations (used to) travel to Syria on a regular basis for leisure, commerce, and healthcare purposes. Healthcare in Syria is free, contrary to Lebanon's exuberant charges. In this sense, the hegemonisation of the discourse of the Syrian Other is made possible by the intertwinement of class with its political elite.

The call for the return of the "authentic Lebanese Man" can also be observed in a non-heterosexual context, to name the reiteration of the Syrian refugee male as "bottom" - the bottom being the male who is being penetrated by another male. In a comprehensive work, Bruce Dunne (1998) shows how a hierarchy of masculinities in the Middle East goes hand in hand with particular sex acts; he reminds us, "sexual relations, whether heterosexual or homosexual, are understood as relations of power linked to rigid gender roles" (1998:10). Sexual acts, if we are to follow Dunne, are less invested with desire and physical attraction, and more concurrent with reiterating one's masculinity. By being the "top," a man asserts his domination; the bottom is concurrently construed as a "lesser" man. In more recent works, Massad $(2002,2008)$ argues that same-sex sexual relations in the Middle East do not necessarily correspond to a strict homosexual identity.

Indeed, when former Iranian president Ahmadi Najad infamously said "there are no gays in Iran," he was indirectly referring to what Joseph Massad calls "The Gay International." The Gay International agenda, according to Massad (in Éwanjé-Épée and Magliani-Belkacem 2013) forces post-Empire sexual identities into a homo/hetero binary. The Massad debate is ongoing, to say the least. As far as my reading of Massad goes, I believe that Massad is neglecting the subjectivity and agency of selfdefined LGBT individuals in the Middle East. Perhaps, LGBT identities in the Middle East are informed locally in a way that distinguishes them from the western conceptions, but by dismissing them entirely as he does, Massad is merely reiterating an East vs. West discourse, which induces the rhetoric of a Middle Eastern masculinity in crisis.

The alarming narrative of the "bottom" Syrian Other was shared by a number of self-identified gay Lebanese men I interviewed. Moreover, many viewed their Syrian counterparts' mannerisms, way of talking, and style of clothing as too "effeminate," therefore hindering the "advanced stage" of LGBT activism in Lebanon, part of which is invested in educating society that "not all gays act gay." I argue that the reiteration of the Syrian refugee as "necessarily bottom" in a same-sex context functions along the very structure of the "reclaimed Lebanese man." The Lebanese male constructs himself as the more masculine, therefore relocating masculinity from an emasculated element (Syrian) to a hyper masculine one (Lebanese). Such uncomfortable findings are important to state, and their relevance will become clearer as I develop my paper.

\section{The Limits of Asylum Organizations}

While it is compassionate to insist that queers need refuge in the West on account of the persecution they face, it's short-sighted to assume that asylum is the perfect solution [...] What concerns me is that we rush to paint all those other countries as universally hostile to queers without understanding the larger contexts in which that violence is bred... Do we understand 
the lives of persecuted queers alongside the lives of non-queers who are brutalized, physically and economically, but have no recourse to asylum? (Nair, cited in Chavez 2013: 69).

Asylum officials make sharp distinctions between LGBT refugees and the rest, which is a limiting and hindering framework to begin with. This distinction, which is reinforced by distinct administrative practices, supposes that LGBT refugees, contrary to the rest of refugees, have fled Syria for distinct reasons. Such an approach diminishes the urgency of the ongoing war in Syria: the LGBT refugee is co-opted into a narrative of a better future elsewhere (in the west), whilst the war in Syria is barely addressed and is instead normalized in vein with further western-backed military operations across the MENA. To illustrate this point, I turn to my fieldwork. When I asked Umar and Ahmad whether they've fled to Lebanon because it is "more gay friendly," Ahmad remarked that "Lebanon is not necessarily more gay-friendly" especially since he fled along with his family from whom he keeps his sexual orientation hidden. Umar, on the other hand, had fled alone and joined Ahmed a couple of months later. Unlike Ahmad, Umar remarked that he found plenty of support among NGOs in Lebanon, and "unless one goes to dangerous places, [he finds] Lebanon to be generally safe."

Unsurprisingly, among the "dangerous places" cited are LGBT-friendly NGOs and asylum organizations. Many of my interlocutors feared being seen around such supposedly "safe spaces." If anything, my fieldwork informed me that asylum officials, through their monolithic understanding of what a non-heterosexual life ought to be acted like, indirectly force LGBT refugees into a visible corporeality, therefore hindering their very existence. Asylum officials systematically reproduce the western narrative of "coming out," which is highly at odds with the lived reality of LGBT individuals in the region. If anything, my fieldwork informed me that a discreet way of life and "not drawing attention to one's self" was the preferred survival strategy. This discretion is exemplified in the example of GHOST club above, where "deviant sex" was pinned onto Syrian bodies exclusively, despite the club being abundant with non-Syrian, and possibly Lebanese patrons.

Another "dangerous" space recognized by my interlocutors is asylum officials' conflation of homosexual desire with non-religiosity. Asylum officials' misappropriation of the role of religion proved particularly difficult to those interlocutors who considered themselves highly pious. At the same time, the assumed non-religiosity of LGBT individuals indirectly ascribes religion to non-LGBT bodies, as if non-LGBT bodies do not count atheists or non-religious individuals among them. Furthermore, the assumed nonreligiosity of LGBT identities approximates them to the "secular" west whilst reinforcing it as off-limits to religious - or "terrorist unless proven otherwise" - asylum seekers. Conversely, and particularly in the context of Europe, several authors have examined legal and cultural discourses in order to un-do Europe's secular myth, and to show how secularism becomes instrumental for the emergence of nationalist narratives and the creation of Others (Haritaworn 2012, El-Tayyeb, 2011). The conflation of secularism with the absence of terrorism imagines non-normative identities as not capable of violence, which is not necessarily the case, as my meeting with Taha informed me. If anything, by constructing LGBT agents as non-violent, asylum officials indirectly reproduce normative identities as "potential terrorists," and contribute to the "securitization" of sexuality. ${ }^{6}$

\footnotetext{
${ }^{6}$ See the work of Bazen, Waever, and de Wilde (1998) from the Copenhagen School on non-traditional threats and securitization.
} 
I met Taha during an Iftar gathering for LGBT refugees in Lebanon hosted by a local NGO in Beirut. Taha, an Alawite, came to Lebanon in 2008, at least two years before the beginning of the popular uprisings in Syria. At the time, he sought Lebanon in the hope to find a "home" where he could "be at peace with his sexuality." He had been sharing a flat with three gay Sunni Lebanese men since his arrival. His Alawite faith "has never been an issue" between him and his flatmates, at least not until the summer of 2014.

The summer of 2014 was particularly bloody in Lebanon. There were so-called sectarian clashes (a misnomer, in my opinion) in Tripoli7 between Alawite and Sunni militias, and several car bombs in Beirut as a "retaliation" for Hezbollah's participation in the war in Syria along Bashar Al-Assad troops. Taha, during the summer of 2014, was expelled from his flat because "his flatmates had had it with Hezbollah's actions in Syria." Moreover, Taha informed me that on the day he left his flat, he was attacked by a gang of masked men "who knew exactly when he was due to leave his flat." They took his only luggage where he had packed all his possessions, in addition to his wallet. On the day I met him, "he had absolutely nothing," and had to rely on his connections to a local. Whereas his flatmates had ignored, perhaps even deliberately neglected, his Alawite faith up to the summer of 2014, he soon found himself cast away because of it. Moreover, his flatmates, before the war(s) in Syria, would often tease him amicably about his anti-Bashar sentiments, seeing that the latter, too, is Alawite.

Taha's narrative is twofold. On the one hand, his ex-flatmates' actions betray asylum officials' conflation of non-normative identities with non-violence. At the same time, we learn from the events in Taha's life that at times of increased militarization, the "location of homophobia," to borrow from Rahul Rao (2014) changes, in addition to operating in conjunction with a nationalistic masculinity. Taha's narrative, in many ways, empirically captures what Jasbir Puar terms "homonationalism." In addition, his narrative ultimately shows how identity politics are best understood along an exercise of assemblage, considering the fact that identity politics are not as fixed as we presume them to be, and are always in tandem with larger geopolitical and socioeconomic shifts.

In her mythical 2005 work, Terrorist Assemblage, Puar shows how U.S. administrations post 9/11 constructed homophobia as a foreign element through the assimilation of non-normative sexualities' narratives to those of the American nation. 9/11 produced an array of American heroes, many of whom

\footnotetext{
${ }^{7}$ Tripoli is a city located roughly 80 kilometers from the capital Beirut. It is commonly referred to as the "mother of the poor." No less than 29 rounds of armed clashes have occurred during the year 2014 in the neighborhood of Tebbaneh, one of Lebanon's poorest and most neglected neighborhoods. The clashes occurred between Sunni and Alawite militias on the one hand, and between these militias and the Lebanese army on the other. They are in part the result of the participation of the Shi'a party of Hezbollah in the Syrian war along Bashar Al-Assad's forces. The clashes are often presented as the answer to Hezbollah's participation: the Sunni militias taking up arms against the pro-Assad Alawite militias. To qualify these clashes as sectarian is problematic, seeing that Sunnis and Alawites have co-existed for centuries in Tripoli. They have, and continue to inter-marry, in addition to co-jointly leading successful businesses. Moreover, the clashes are often carried by militia groups that are "elusive in nature" (Milligan, 2014). By elusive, I mean that they constantly "shift their allegiance" to local patrons, which clearly shows the shortsightedness of an analysis that views them along the lines of a sectarian ideology (ibid). Maren Milligan recently remarked that an emphasis on the sectarian nature of the conflict in Tripoli and its reduction to questions of sectarianism, security, or spillover from the Syrian war "absolves international actors of an obligation to address the conflict since efforts will not bear fruit until the Syrian crisis is resolved" (2014).
} 
pertained to the LGBT community. More recently, the Obama administration repelled the "Don't Ask, Don't Tell" practice in U.S. military, and legalized same-sex marriage in 2015. The instrumentalization of LGBT narratives for the sake of the nation reproduces the U.S. as a haven of sexual equality whilst simultaneously erasing its long history of homophobic attitudes and practices towards LGBT individuals. Following 9/11, homophobic practices are henceforth located in foreign bodies, notably Muslim and brown migrants.

As a consequence of the normalization of LGBT identities, homonationalists engage in nationalistic politics at the expense of intersectional activism. An example of homonationalism can be found in the infamous figure of Milo Yiannopoulos, whose unleashed nationalistic values emerge alongside xenophobic, islamophobic, and racist ones. Another example is Israel's mechanism of Pinkwashing, a "deliberate strategy used by Israel's government, agencies, and the Israeli LGBT community to exploit Israel's relatively progressive stance on gay rights, and to deflect international attention from its gross violations of human rights and international law" (Shafie 2015: 84). Pinkwashing allows Israel to proclaim itself as the sole guarantor of LGBT rights in the MENA region, thus reproducing the Arab world as inherently violent and homophobic.

In order to fully grasp how homonationalism relocates homophobia from the inside to the outside, it helps to think of homophobia along vertical and horizontal lines. Vertical homophobia emerges from "sociopolitical structures and institutions" that characterize the state, whereas horizontal homophobia refers to the "penetration of everyday, interpersonal, and psychological life by anti-homosexual discourse" (Ratele 2014: 120). Vertical and horizontal homophobia are not in tandem: anti-homophobic laws do not necessarily reproduce an LGBT-friendly society, and anti-homosexuality laws do not necessarily reproduce a homophobic society.

If we take the case of the Arab world, a post-colonial context par excellence, the literature informs us of a rich history of diverse sexual lives across its societies. At the same time, the artificial construction of the Middle East into various nation-states whose legal and governmental systems were imposed directly by colonial powers led to the gradual replacement of local knowledges with western-imbued ones, including where sexual rights are concerned. My fieldwork informed me that many LGBT individuals in Lebanon were able to forge safe spaces for themselves among friends, sympathizers, and sometimes their family, which reflects the limits of horizontal homophobia in the Lebanese context, despite the anti-homosexuality article $534 .{ }^{8}$ These limits, however, are linked to one's class, social background, level of education, and geographical location, and are therefore highly irregular. In addition, these limits must be thought of in conjuncture with the Lebanese state, as we saw earlier with the contrasting examples of Cinema Plaza and GHOST nightclub.

Inherent to homonationalism is what Rao terms "homocapitalism." or the "selective incorporation of some race-, class- and gender-sanitized queers into capitalism, and the disavowal of others (usually migrants, refugees, poor demographics, people of color, women, children, LGBT communities) through

\footnotetext{
${ }^{8}$ Article 534 of the Lebanese Penal Code does not refer to homosexuality per se. Rather, it refers to sexual relations that contradict the laws of nature. Nevertheless, it is the invoked article in situations where same-sex practices are suspected.
} 
a liberal politics of recognition that obviates the need for redistribution" (Rao, 2015: 47) (my addition). Homocapitalism, as a concept, allows us to come to term with the intersection of a capitalist economy and class with identity politics.

The combination of homonationalism with homocapitalism compels us to examine identity politics beyond an intersectional lens by asking questions such as what does it mean when LGBT narratives are co-opted by the very same structures that have historically led to their marginalization? What does it mean when the struggle for identity politics no longer operate in contra of the very same structures that de facto led to their marginalization in the first place? In other words, how can we account for the actions of Taha's ex-flatmates? Answering such questions compel us to stretch the scope of an intersectional analysis by combining it with an exercise of assemblage, in line with Jasbir Puar's recommendations.

The self-identified LGBT Syrian refugees I met often "juggled" multiple lives at once; not in the sense that they lived hidden/open double lives - itself a highly contentious point seeing how sexuality in the Middle East is often examined through the rather imagined binary of public/private ${ }^{9}$ - rather, in the sense that they would consciously emphasize and/or attenuate certain social categorizations, depending on the context in which they find themself. Each had developed a particular barometer of "public intimacy" whereby they constantly assess the "outside" in relation to their sexuality.

Unsurprisingly, many would exaggerate their sexual identity in order to convince their interviewers that they are persecuted to the point that asylum must be granted to them. In particular, they would inject their narratives with stereotypical narratives widely associated with the figure of the "happy queer," such as an inclination to party, shunning religion, and an openness to all things "western." Such findings bring forth both the relationship of asylum officials to gender activists in Lebanon, and Joseph Massad's concept of the Gay International.

Many asylum officials who were in charge of LGBT applications worked closely with gender activists. Gender activists ${ }^{10}$ in Lebanon, unsurprisingly, find their activism criticized both locally and globally. In a poignant piece written in 2015, Lama Abu-Odeh remarks how local gender activists in the Arab world "face censure from their own societies," who accuse them of importing foreign narratives, "and attacks by US-based anti-imperialist scholars who charge them with complicity with western imperialist designs" (Abu-Odeh, 2015) (my emphasis). Abu-Odeh's remarks resonate highly with my fieldwork findings. Many of the gender activists I spoke to, including those who work with asylum organizations, negotiate their labour alongside highly constraining kin relations, and often find themselves torn between work, anti-imperial resistance, and familial obligations. In addition, the majority were aware of the limits of

\footnotetext{
${ }^{9}$ For feminist, and queer critiques of the public/private binary in Lebanon and elsewhere, see Gagné and Qubaia (2013), and Yuval-Davis (1997).

10 I use the expression "gender activists" rather broadly here. It is important to note that it would be erroneous to think of gender activists in Lebanon in a monolithic way. Whereas some gender activists limit their activism to the elitist and exclusionary frame of state-feminism, others, through their affiliation to global NGOs reproduce imperialist hierarchies. At the end of spectrum are those activists who distance themselves from the two and engage in intersectional work, thus recognizing the intersections between gender, class, sect, nationality, etc.
} 
asylum organizations' approaches. Not only do their views coincide with my own observations, some bring forth Miranda Joseph's critique of the ngo-ization of sexual rights:

In late capitalism much of what is considered "community" is promulgated by non-profit organizations that are developed not to oppose capitalism, but rather to fill in its gaps by providing services, resources, and entertainment to local communities. (Joseph, cited in Chavez 2013: 72).

Joseph's remarks are echoed by Maher, a 28 years old gender consultant for an international NGO based in Beirut:

Of course it's not ideal. But what is one to do? Sit aside and watch? Who cares if the whole process is based on enactment as long as it gets you your salary? Our donors are oblivious to the reality we work in. Competition is tough. Everyone wants to get their hands on the funding. Without finding, there is no salary. We know what they [our donors] want, and we write our proposals accordingly.

Asylum officials' "checklist" approach is reminiscent of Joseph Massad's work on the Gay International agenda that forces post-Empire sexualities into a homo/hetero binary. Whereas Massad's work does resonate indeed in the particular context of refugees being interviewed by asylum organizations, it does not necessarily fit with the systematic way in which Massad portrays local LGBT agents, and which I have criticized earlier.

Massad aside, the tensions raised so far reflect the complexity of the lived reality of my interlocutors. On the one hand, the reiteration of the stereotype of the "happy queer" forces LGBT refugees into a visible (least desirable) existence. On the other hand, this reiteration is seen as a strategy to legitimize and "prove" one's sexual orientation. The embracing of the stereotype of the "happy queer" is tantamount to the concept of "being willful" as posited by Sara Ahmed. Ahmed (2010) evokes antiracist, feminist, and queer critiques of "the myth of the happy slave," of "the figure of the happy housewife," and of heterosexuality's "domestic bliss" respectively, to argue that the struggle over happiness provides the horizon in which political claims, i.e. being willful, are made.

The exceptionalisation of LGBT narratives by asylum officials is almost absurd once we take into consideration the intersection of sexual identity with further social categories, particularly class. In reality, an L, G, B, or T label does not necessarily mean a marginalized life. Many hetero identities find themselves as marginalized as non-hetero ones, especially if they engage in anti-establishment politics. In other words, one could very much be hetero and queer in as much as one could be $L, G, B, T$, or else, and not queer. This is exactly why I have opted for using the LGBT acronyms in this paper so far. My understanding of a queer identity is one that challenges the fundamental foundations of the racial, gendered, capitalist, and white structures that inform modern life, in addition to recognizing and calling out homonationalist practices, or as Nair puts it:

Queer organising used to be [about] dismantling economic structures of privilege and redefining structures of kinship in ways that straights have since embraced. Somewhere along 
the way, we - or rather, the increasingly powerful gay organizations that speak for us and articulate 'our' agenda - have decided that we want to expand, not destroy, privilege. Instead of fighting for basic rights for everyone. (Nair, cited in Chavez 2013: 72)

The actions of Taha's ex-flatmates, for instance, reinforce the slogan of "Lebanon is for the Lebanese." Seen from a critical queer lens, there is hardly any oppositional politics in their actions, despite them identifying as gay.

The constant tension between sex narratives and the nation-state produces historically specific attitudes towards sexuality. We saw in the case of Taha how his Alawite faith went unchallenged by his Sunni ex-flatmates until the summer of 2014. In this regard, even in the case of horizontal homophobia, further factors such as sect can lead to further systems of inclusion/exclusion. It is clear then that in order to have a full grasp of identity politics, it is important that we examine them in juncture with further affective mechanisms. Puar's recommendation to combine intersectional analysis with an exercise of assemblage is on point, and theoretically enriching for both political analysts and policy makers.

\section{Re-thinking Intersection in Intersectionality}

Puar views intersectionality as a becoming, which is considerably different from the rather "fixed" meaning that Kimberlé Crenshaw ascribed to it when she first coined the term in 1989. When Kimberlé Crenshaw put forth the concept of intersectionality, she did it in the context of domestic violence. Crenshaw's ultimate goal, and rightly so, was to explain that the category of gender alone cannot account for the fate of the women involved. Rather, gender as a category intersects with an array of categories, each with its own structural logic of dominion, to name race, class, nationality, age, and so on. Crenshaw renders her concept empirically accessible by liking it to analogy of "a traffic in an intersection:"

Discrimination, like traffic through an intersection, may flow in one direction, and it may flow in another. If an accident happens in an intersection, it can be caused by cars traveling from any number of directions and, sometimes, from all of them. (Crenshaw cited in Puar 2013: 382)

At the same time, Crenshaw is aware of the difficulty of measuring with minute precision the responsibility of those involved in an accident:

But it is not always easy to reconstruct an accident: sometimes the skid marks and the injuries simply indicate that they occurred simultaneously, frustrating efforts to determine which driver caused the harm. In these cases the tendency seems to be that no driver is held responsible, no treatment is administered, and the involved parties simply get back in their cars and zoom away. (ibid)

Puar is interested in the malleability of identity politics: where do they emerge? Why then? Why now? What happens next? Why wasn't Taha's Alawite faith an issue prior to the summer of 2014? Starting from such a position, Puar is interested in "what is prior to and beyond what gets established [i.e, the 
accident]" (Puar 2013: 388). She notes the irony that permeates an intersectional analysis seeing how intersectionality produces the very same Other it is originally "meant to alleviate," i.e. "women of colour" (Puar 2013: 274). Her views are fathomable in the context of women's studies in the U.S., where intersectionality acquires a rather "overdeterministic" character (an intersection) in its over emphasis on identity politics at the expense of a structural critique of power. In the same vein, Lugones (2007) views intersectionality as a descriptive tool above all, and argues that far from liberating the identities it engages with, intersectionality fixes them.

Drawing on Crenshaw's analogy of the crossroad, Puar argues that "the focus here is not on whether there is a crime taking place, nor determining who is at fault, but rather asking what are the affective conditions necessary for the event-space to unfold" (Puar 2013: 385). For Puar, identities are not merely intersectional but emerge alongside an assemblage of further mechanisms of surveillance and discipline that operate at the level of society as a whole:

To dismiss assemblage in favor of retaining intersectional identitarian frameworks are to miss the ways in which societies of control apprehend and produce bodies as information, and surveilles bodies not on identity positions alone but through affective tendencies and statistical probabilities. (Puar 2013: 387)

To add complexity to Puar's argument, I turn to the work of queer anthropology scholar Mark Graham. Graham (2014) uses the example of the Gravelly Hill Interchange on the M6 motorway in Birmingham in order to envisage intersectionality as the simultaneity of several crossroads, some floating in parallel, some in opposition, some intersecting, and some overarching. At times, some roads intersect and others don't. Equally, these roads are not monolithic. They might look like roads, but there are pathways, highways, and toll ways, to name a few.

When we contemplate intersectionality from such an angle, and when we situate it along homonationalist and homocapitalist structures, we are hit by the colossal magnitude of the web of structural powers that simultaneously produce intersectional identities and societies of surveillance, hence the importance of examining the space between them. The making and un-making of homophobic laws in the case of homonationalism, the enactment of the "happy queer," the targeting of Syrian patrons in GHOST, and the example of Taha in particular are examples that compel us to examine identity politics beyond the intersection at which they emerge.

An increasing number of scholars share Puar's take on intersectionality, including Singh (2015), Chow (2005), and Chávez (2013), to name a few. Chavéz (2013: 58) remarks how an exercise of assemblage emphasizes "movement, flow, and affectivities," which is in sharp contrast to the fixity of intersectionality. Such fluidity allows assemblages to account for "other contingencies of belonging" that the intersectionality-informed framework of identity politics "may not account for" (Puar 2005: 211).

\section{Empirical Usage of Assemblage in the Context of Asylum Organizations}

In this concluding section, I empirically capture the theoretical recommendations of Puar by relating 
innovative recommendations put forth by gender activists who work closely with asylum organizations.

In the context of asylum organizations, Abu-Assab, Nasser-Eddin, and Greatrick (2017) recommend a shift from sexual orientation and gender identity (SOGI) to what they term sexual practices and gender performance (SPGP). Drawing on data recollected across 22 Middle Eastern countries, the authors remark that oftentimes persecution occurs when sexual practice and gender performance do not reproduce normative expectations. In other words, even in a heterosexual context, men and women who not adhere to societal expectations related to hegemonic masculinities or feminities do face instances of severe persecution, and despite this reality, they are not considered persecuted per se by asylum officials, who adhere to strict international legal formulations. The authors point out the asymmetry between the lived reality (persecution based on gender performance) and asylum officials' demarcation of persecution (sexual identity), and rightly call for "centralizing sexual practice rather than sexual identities" within "humanitarian responses" (Abu-Assab et al 2017: 14). Among the cases they relate are cis heterosexual men being persecuted "due to their feminine performances," or cis heterosexual women who engage in sex outside marriage. Most importantly, the authors draw our attention to the deeply rooted male/female binary that informs performances of masculinities and femininities in the MENA region. As such, individuals whose lived reality correspond to the concept of "gender-as-spectrum" are stigmatized, and for lesbian women, for instance, rather than their status as lesbian, it is the category of woman itself that inform their personal and political struggle.

Our authors' analysis diverges from a purely intersectional one. Whereas intersectionality allows them to describe the multiple struggles their interlocutors face, they link it to further gendered affectivities in order to draw their recommendation, which clearly echoes the work of Puar.

In the context of the U.S., queer radical activist Yasmin Nair bemoans the practice of celebrating "personal narratives" in the context of LGBT migrants who happen to be partners of U.S. citizens or legal permanent residents" (Nair cited in Chavez 2013: 50-51). Personal narratives are stories of success (or failure if we follow Nair's logic) that capture the intersection of migration politics with LGBT lives in the U.S., and are often deployed by liberal LGBT activists in order to "celebrate" the Uniting Families Act. For Nair such practices adhere "to a sentimental and nostalgic view of the Other [that] is deeply embedded in politics of abjection and rescue" (Nair cited in Chavez 2013: 60). Personal narratives, despite them embedding highly individualized intersectional struggles, provide asylum officials with an ideal opportunity to reproduce the west as the ultimate "happy place." At the same time, they focus on the few, and leave unattended the struggles of the majority who are yet to be "fallen in love" with. Ultimately, Nair argues that "achieving liberation is a matter of changing deep structural conditions as opposed to enacting individual (or even some form of collective) agency" (Nair cited in Chavez 2013: 62). It is only through a balancing exercise between intersectionality and assemblage that deep structural conditions can be shaken. 


\section{References}

Abu-Assab, N., Nasser Eddin, N., and Greatrick, P., 2017. Conceptualising Sexualities in the MENA Region: Undoing LGBTQI Categories. London: Centre for Transnational Development and Collaboration.

Abu-Odeh, L., 2015. "Holier Than Thou?: The Anti-Imperialist versus the Local." Open Democracy. https://www.opendemocracy.net/5050/lama-abu-odeh/holier-than-thou-antiimperialist-versuslocal-activist (last accessed 19 April 2017).

Ahmed, S., 2000. Strange Encounters: Embodied Others in Post-Coloniality. Oxon: Routledge.

---. 2010. "Feminist Killjoys (and Other Willful Subjects)." Polyphonic Feminisms: Acting in Concert 8:3. http://sfonline.barnard.edu/polyphonic/print_ahmed.htm (last accessed 20 April 2017).

Amar, P., 2011. "Middle East Masculinity Studies Discourses of 'Men in Crisis,' Industries of Gender in Revolution." Journal of Middle East Women's Studies 7, 36-70.

---. 2013. The Security Archipelago: Human-Security States, Sexuality Politics, and the End of Neoliberalism. Durham and London: Duke University Press.

Assaf, G., and El-Fil, R., 2000. "Resolving the Issue of War Displacement in Lebanon." Forced Migration review 7, 31-33.

Buzan, B., Wæver, O., and de Wilde, J., 1998. Security: A New Framework for Analysis. London: Lynne Rienner Publishers.

Chavez, K.R., 2013. Queer Migration Politics: Activist Rhetoric and Coalitional Possibilities. University of Illinois Press.

Cockburn, C., 1999. "Gender, Armed Conflict and Political Violence." Background paper presented at The World Bank, Washington DC, June 10 \& 11, 1999. repository.forcedmigration.org/pdf/?pid=fmo:5013 (last accessed 20 April 2017).

Czajka, A., 2012. "Discursive constructions of Palestinian Refugees in Lebanon: From the IsraelHezbollah War to the Struggle over Nahr al-Bared." Comparative Studies of South Asia, Africa and the Middle East 32:1, 238-254.

Dunne, B., 1998. "Power and Sexuality in the Middle East." Middle East Report 206, 8-11.

El-Tayeb, F., 2011. European Others. Queering Ethnicity in Postnational Europe. Minneapolis: University of Minnesota.

Éwanjé-Épée, F.B., and Magliani-Belkacem, S., 2013. "The Empire of Sexuality: An Interview with Joseph Massad." Jadaliyya, http://www.jadaliyya.com/pages/index/10461/the-empire-ofsexuality_an-interview-with-joseph-m (last accessed 21 April 2017).

Gagné, M., and Qubaia, A., 2013. "The Delusions of Representing Male Homosexuality in Beirut." Jadaliyya. http://www.jadaliyya.com/pages/index/15807/the-delusions-of-representing-malehomosexuality-i (last accessed 18 April 2017).

---. 2014. "Sexualizing and Villainizing Male Syrian Refugees in Lebanon." Muftah. https://muftah.org/sexualizing-and-villainizing-syrian-refugees/\#.VMertP7F_T8 (last accessed 17 June 2017).

Graham, M., 2014. Anthropological Explorations in Queer Theory. Oxon: Routledge.

Halabi, Z., 2004. "Exclusion and identity in Lebanon's Palestinian Refugee Camps: a Story of Sustained Conflict." Environment and Urbanization 16, 39-48. 
Haritaworn, J., 2012. "Colorful Bodies in the Multikulti Metropolis: Vitality, Victimology and Transgressive Citizenship in Berlin." In: Cotten, Trystan T. (Eds.), Transgender Migrations. The Bodies, Borders, and Politics of Transition. New York: Routledge.

Joseph, S., 2005. "The Kin Contract and Citizenship in the Middle East." In: Friednman, Marilyn (Eds.), Women and Citizenship. Oxford: Oxford University Press.

Knudsen, A., 2009. "Widening the Protection Gap: The 'Politics of Citizenship' for Palestinian Refugees in Lebanon, 1948-2008." Journal of Refugee Studies 22, 51-73.

Makdisi, S., and El-Khalil, Y., 2013. "Lebanon: The Legacy of Sectarian Consociationalism and the Transition to a Fully-fledged Democracy." Issam Fares Institute for Public Policy and International Affairs. https://www.aub.edu.lblifi/public_policy/rapp/Documents/working_paper_series/20130301samir _makdesi_youssef_khali__rapp_wp.pdf (last accessed 17 June 2017)

Mandour, S., 2013. "Potential Change in Media Discourse on Sexuality in Lebanon: Cinema Plaza and Beyond." Reuters Institute for the Study of Journalism, https://reutersinstitute.politics.ox.ac.uk/sites/defaultffiles/Potential\%20Change\%20in\%20Media \%20Discourse\%20on\%20Sexuality\%20in\%20Lebanon.pdf (last accessed 09 March 2017).

Massad., J.A., 2002. "Re-Orienting Desire: The Gay International and the Arab World." Public Culture 14:2, 361-385.

--- 2008. Desiring Arabs. Chicago: Chicago University Press.

Milligan, M., 2014. "Making Sense of Tripoli I: The Security Trap or Conflating Cause and Effect." Jadaliyya. http://www.jadaliyya.com/pages/index/20179/making-sense-of-tripoli-i_the-securitytrap-or-con (last accessed 21 March 2017).

Nagel, J., 1998. "Masculinity and Nationalism: Gender and Sexuality in the Making of Nations." Ethnic and Racial Studies 21:2, 242-269.

Peteet, J.M., 2005. Landscape of Hope and Despair: Palestinian Refugee Camps. University of Pennsylvania Press.

Pratt, N., 2007. "The Queen Boat Case in Egypt: Sexuality, National Sovereignty and Security." Review of International Studies 33, 129-144.

Puar, J.K., 2005. Terrorist Assemblages: Homonationalism in Queer Times. Duke University Press.

--. 2012. "I Would Rather Be a Cyborg than a Goddess: Becoming-Intersectional in Assemblage Theory." Meritum Belo Horizonte 8:2, 371-390.

Rao, R., 2014. "The Locations of Homophobia." London Review of International Law 2:2, 169-199.

--. 2015. "Global Homocapitalism." Radical Philosophy, 194, 38-49.

Ratele, K., 2014. "Hegemonic African Masculinities and Men's Heterosexual Lives: Some Uses for Homophobia." African Studies Review 57:2, 115-130.

Raynbow Lebanon, 2013. Lebanese Broadcasting Corporation (LBC) News bulletin, 25 April 2013, https://www.youtube.com/watch?v=UXfb40nRazA (last accessed 18 April 2017).

Roberts, R., 2011. "Palestinians in Lebanon: Refugees Living with Long-Term Displacement." Journal of Refugee Studies 24, 416-417.

Shafie, G., 2015. "Pinkwashing: Israel's International Strategy and Internal Agenda." Kohl: a Journal of Body and Gender Research 1:1, 82-86. 
Turner, L., 2015. "Explaining the (Non-)Encampment of Syrian Refugees: Security, Class and the Labour Market in Lebanon and Jordan." Mediterranean Politics 20:3, 386-404.

Yuval-Davis, N., 1997. "Women, Citizenship, and Difference." Feminist Review 57, 4-27. 